\title{
Geo-Electric and 3D-Imaging of Groundwater Distribution along Flood Plain Deposits of River Niger at Jebba, North-Central Nigeria
}

\author{
Alao D. A. ${ }^{1}$, Amadi A. N. ${ }^{2}$, Adeoye Yinka ${ }^{3} \&$ Oladipo A. V. ${ }^{4}$ \\ ${ }^{1}$ Victorville CA, USA \\ ${ }^{2}$ Federal University of Technology, Minna, Nigeria \\ ${ }^{3}$ Edmonton, Alberta, Canada \\ ${ }^{4}$ Unilorin, Nigeria \\ Correspondence: Amadi A. N., Department of Geology, Federal University of Technology, Minna, Nigeria. \\ Tel: 234-803-772-9977. E-mail: geoama76@gmail.com
}

Received: December 25, 2012 Accepted: February 20, 2013 Online Published: February 22, 2013

doi:10.5539/enrr.v3n2p61 URL: http://dx.doi.org/10.5539/enrr.v3n2p61

\begin{abstract}
Twenty five profiles of Vertical Electrical Sounding were obtained at Jebba area, North-central Nigeria with the aim of ascertain the nature of groundwater distribution in the area. The area is characterized by arid climate of low rainfall and high evaporation. The old alluvial plains surface is covered with a silty-sand and gravel which are subject to new reclamation. The first sedimentary cover unit $<0.5 \mathrm{~m}$ is draped by silty-clay causing some of the area under analysis to be water-logged. It is underlain by a sandy layer more than one meter thick beneath the surface. The geo-electric cross-sections produced from the interpreted twenty five VES data using iterative computer program revealed three to four geo-electric layers. The top most layer ranged between $5 \Omega \mathrm{m}-1722 \Omega \mathrm{m}$ and is suggestive of lateritic clay with a thickness of 0 m-1.5 m. Layer two has thickness of $1.5 \mathrm{~m}-28 \mathrm{~m}$ with an average apparent resistivity of $30 \Omega \mathrm{m}-122 \Omega \mathrm{m}$ and is suggestive of weathered basement layer. Layer three has a geo-electric layer of thickness between $28 \mathrm{~m}-45 \mathrm{~m}$ with an average apparent resistivity of between $50 \Omega \mathrm{m}-350$ $\Omega \mathrm{m}$ which is suggestive of partly weathered/fractured basement and fourth layer suggestive of the fresh basement. The geo-electric sections suggested two system aquifer, weathered layer aquifer system and the partly weathered/fractured basement aquifer system. These aquifer units possess largely good hydraulic characteristics and groundwater potential. This study enables the delineation of shallow aquifers, their subsurface disposition and identified promising areas for elaborate groundwater development in the area. An integration of such hydro-geophysical study with lithologic logs/drilling data would enhance accurate delineation of aquifers of the study area. Another high point of this study is the application of the leapfrog hydro software to prepare 3D Imaging of the sub-surface and to delineate areas high groundwater potentials.
\end{abstract}

Keywords: geoelectric-cross-section, floodplain, VES, 3D-Imaging, groundwater distribution, Jebba

\section{Introduction}

River Niger floodplain in Jebba area is part of basement complex of North-central Nigeria. The basement complex at Jebba area consists of ridges of various rock types, such as quartzite, marble, migmatite. The floodplain was developed by the River Niger, taking its course through Jebba area, depositing it sediments (fine sand, silt and clay) by the river sides as the velocity of the river decreases.

The inhabitants are mostly farmers and fishermen who depend mainly on the running water from the streams and very few but deep hand-dug wells, for their domestic use. Most of the boreholes drilled in the area were abortive hole and abandoned. Therefore one of the major challenges faced by most communities in Jebba is the acute shortage of water, consequently, human activities such as domestic, agriculture, and recreation has been greatly influenced due to remoteness of water. Hence the need to accurately delineate the zone of high groundwater potential and this is what gave rise to the present study.

This study is aimed at characterizing the aquifer system in the study area, in terms of geometry, groundwater distribution, and the major recharging system using vertical electrical sounding (VES) of schlumberger array at strategic locations. The resistivity $3 \mathrm{D}$ models were used to construct a geoelectrical cross-section to define subsurface stratigraphy units, including 3D imaging to reveal the groundwater distribution. 


\section{The Study Area and Its Location}

The study area is Jabba and environs and it lies between latitude $9^{\circ} 11^{\prime} 29^{\prime \prime} \mathrm{N}$ to $9^{\circ} 06^{\prime} 55^{\prime \prime} \mathrm{N}$ and longitude $4^{\circ}$ $48^{\prime} 24$ " E to $4^{\circ} 51^{\prime} 06^{\prime \prime}$ E (Figure 1). The study area lies within the North-central part of Nigeria, along Ilorin-Bida road.

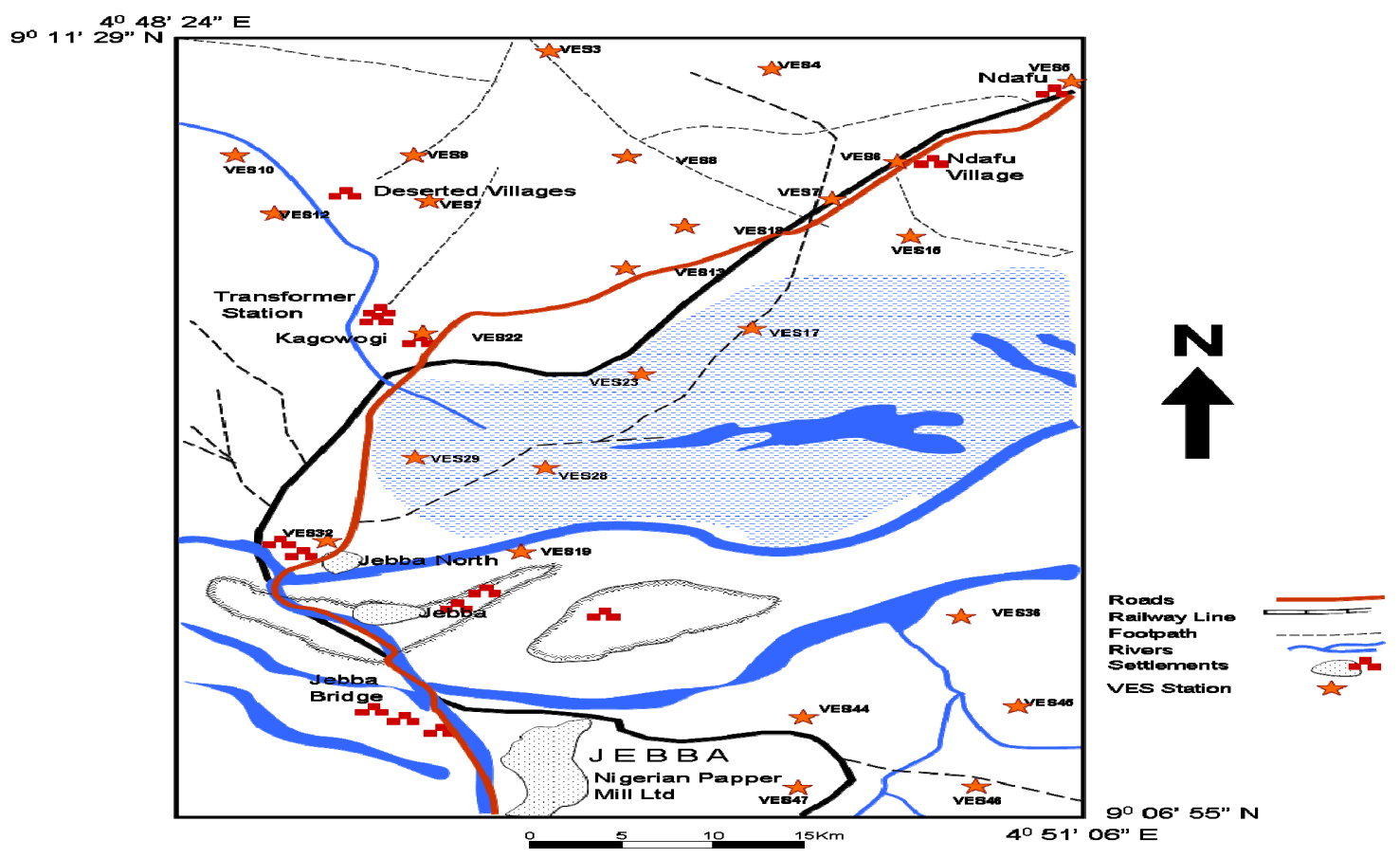

Figure 1. Map of Jebba showing the VES point

\subsection{Accessibility}

The area studied is fairly accessible by footpath, railway tracks, minor and major road especially Ilorin-Jebba-Bida road. Getting to our locations was made possible by footpaths and un-tarred roads, some of which we newly create. Accessibility was hindered by thick vegetation, marshy and swampy areas and rivers.

\subsection{Climate and Vegetation}

The climate of the study area usually alternate between dry and rainy season. The area lies within the middle belt of Nigeria with the total annual rainfall between $1270 \mathrm{~mm}$ and $1524 \mathrm{~mm}$, spread over the month of April to October (Mc Curry, 1973). The highest amount of rainfall is observed in the month of August. Monthly highest temperatures are recorded in $\operatorname{March}\left(35^{\circ} \mathrm{C}\right)$ while the lowest is in August which is about $25^{\circ} \mathrm{C}$ (Ajibade, 1982).

The vegetation of the area is that of Guinea Savannah which comprises of various species of shrubs and forest especially along the stream channels and valleys in the area. The vegetation also consists of short grasses of height 3 to 4.5 meters and trees up to 15 meters high (Ajibade \& Woakes, 1976)

\subsection{Drainage}

The area is well drained by River Niger and River Awun and their tributaries. The drainage systems are dendritic and trellis. Most streams in the study area are seasonal and have dry channels during the dry season. The area consists of gentle slope and the ridges are separated by broad valley. The static water level in the area is low during the rainy season and high in the dry season.

\subsection{Human Settlement and Occupational Activities}

The main settlements are found along the main road Bode Saadu which is the major settlement about $17 \mathrm{~km}$ southwest and is densely populated, the other settlement found in this area are hamlet in which the Fulani lives. The activities in this area include farming, cattle rearing by Fulani herdsmen, fishing and lumbering activities. Major cash crops produced include guinea corn, rice, maize, cassava, and yam. Yoruba, Hausa, and the Fulani's are the major ethnic groups inhabiting the study area. The settlement is mainly confined to the eastern half and they are linearly distributed along the minor road and footpaths. 


\subsection{Regional Geological Settings and Geological Background}

The study area lies within the Nigeria Basement Complex which covers about $60 \%$ of land area of the country and it is overlain by cretaceous and tertiary sedimentary basin. It consists of a suite of Precambrian rocks, which include Migmatized gneisses, schist, quartzite, amphibolites, and other are non-fractured granite and diorite (Ajibade \& Woakes, 1976). It is established that the basement complex witnessed a major tecto-thermal event about $600 \pm 100$ mya. It has also been verified from isotopic data that intermittent tectonic and thermal activities involving almost all part of the complex must have taken place prior to late proterozoic to early paleozoic thermal peak.

However, radiometric data from rocks within Nigeria basement rocks indicate at least two orogenic episodes, the eburnean orogeny $(1950 \pm 250 \mathrm{Ma})$; the second orogenic episode older granite cycle (Pan-Africa Orogeny, $600 \pm$ $50 \mathrm{Ma}$ ) culminated in the emplacement of the older granite (Truswell \& Cope, 1963). It has also reported that this basement had been intruded by granite and porphyries of Jurassic age. The intrusive are referred to as younger granites in other to differentiate them from the earlier granites of Precambrian age which are usually referred to as the older granites (Falconer, 1971).

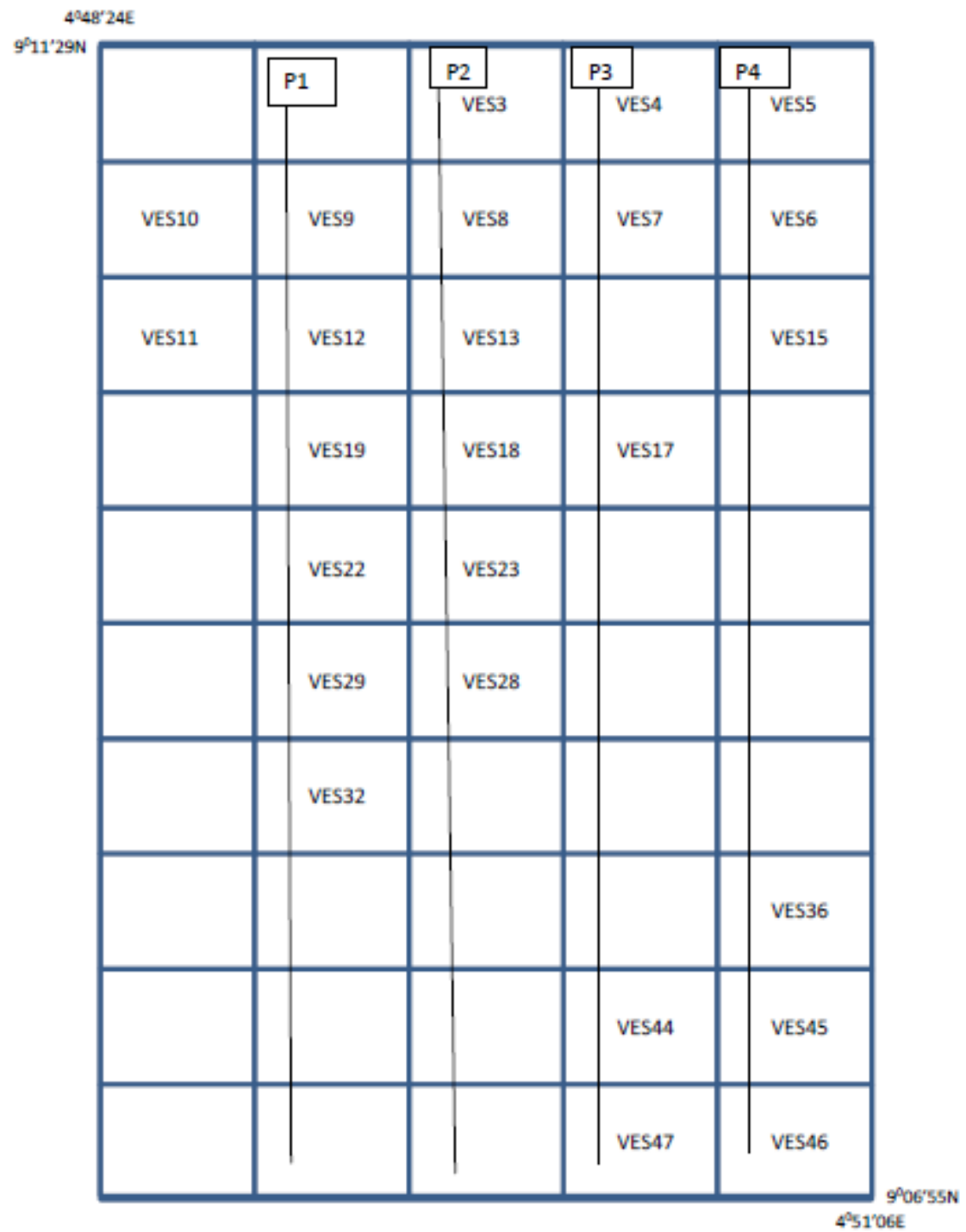

Figure 2. Location map of the VES modeled profiles 


\subsection{Data Acquisition and Interpretation}

A total of 25 VES stations spaced few kilometers apart were established and carried out using Schlumberger array, with a Campus Omega Terrameter and a maximum half current electrode spacing of $50 \mathrm{M}$ since it is a near surface investigation. The main objective is to characterize the distribution of the groundwater in the study area from the subsurface rocks (Alao, 2000; Amadi et al., 2010).

The calculated apparent resistivity values were plotted against half electrode spacing on a log-log graph. The curves obtained were interpreted both qualitatively by inspection and quantitatively by matching small segments of the field curves using three layer model and their corresponding auxiliary curves. The resistivity thickness obtained from the partials curve matching was improved upon by employing iterative computer program to obtain the layers parameter (resistivity, thickness and depth). The numerous layers that were generated by the computer shall be grouped into relevant geologic depth intervals called geo-electric sections. The type of curves (Selemo et al., 1995), the resistivity of the sediment and the knowledge of the local geology were used as guides in the interpretations and analysis of the geo-electric parameters in terms of probable, potable and sustainable water supply. The electrical measurements were carried out along the Jebba valleys which trends in the $\mathrm{N}-\mathrm{S}$ and NE-SW directions. The quantitative interpretation has been applied to determine the thicknesses and true resistivities of the stratigraphic units below each VES station (Zohdy, 1974).

\section{Result and Discussion}

The final digital inversion results of VES interpretation were used for the construction of four geo-electrical cross-sections. The four geo-electric cross-sections were constructed along four profiles oriented approximately $\mathrm{N}-\mathrm{S}$ direction, which coincides with the major fracture pattern and groundwater flow directions. The cross-sections are shown in (Figures 3, 4, 5, and 6) combined with 3D imaging of the groundwater distribution at the N-E, N-W, and S-E profile and illustrated in (Figure 7, 8, and 9) with a geological interpretation of the layers. The models in the cross-sections indicate that the shallow subsurface lithological sequence, in the study area, is represented by three to four geoelectric units with relative resistivities in accordance with the following pattern: $\rho 1<\rho 2>\rho 3<\rho 4$.

\subsection{Geoelectric and Lithological Characteristics}

The geoelectric curves and their corresponding VES data from the study area were categorized accordingly. Curve types identified ranged from simple $\mathrm{H}, \mathrm{A}$, characterized by three layers in most of the study area to HK, $\mathrm{KH}, \mathrm{HA}$, and complex QHKQ etc characterized by four layer types, reflecting facies or lithological variations in the area. The $\mathrm{H}$ curve types were the most dominant curve type. The general signature of the curves suggests alternate sequence of conductive-reflective, resistive-conductive layers, reflecting the unconsolidated nature of the flood plain sequence, characterized by intercalation of gravels, sands and clay/silt. It was responsible for the discrete resistivity layers obtained in the curves.

\subsection{Interpretation of the Geoelectric Sections}

The geo-electric cross-sections generated from the curves suggest three to four layers. These were run in a north-south trend accurately. The geo-electric cross-section along VES points: 4, 7, 17, 44 and 47 (Figure 3) shows a relatively very thick overburden layer which is almost of the same thickness. The geo-electric cross-section along VES points: 5, 6, 15, 36, 45 and 46 (Figure 4) shows a relatively fairly thick overburden sediment and of variable thickness. The geo-electric cross-section along VES points: 3, 8, 18, 13, 23 and 28 (Figure 5) shows a relatively thin aquifer thickness with different depth to surface at different VES station along this trend. The geo-electric cross-section along VES points: 9, 12, 22, 29 and 32 (Figure 6) shows aquifer of very variable surface to basement/depth thickness. Some of this VES point shows very thin unconfined (unsaturated zone) aquifer averaging about $6 \mathrm{~m}$ while some points revealed an aquifer of considerable thickness. This is the interpretations of the 3-D images giving us aquifer characteristics along the directions (traverses) covered by each geo-electric sections and the distribution of the aquifer and the quantitative potential of the groundwater in the three zones. The result shows that, at the north-western part of the River Niger, groundwater potential is low, and at the north-eastern part of the River Niger, the groundwater potential is averagely high while at the south-eastern part of the river, the groundwater potential is very high. It can be ascertained that from the result that groundwater flow highest along the south-eastern bound of the river Niger.

\subsection{Groundwater Distribution}

Electrical methods primarily reflect variations in subsurface resistivity. The electrical resistivity contrasts existing lithological sequences (Amadi and Olasehinde, 2010) in the subsurface are often adequate to enable the delineation of geo-electric layers and identification of aquiferous or non-aquiferous layers (Schwarz, 1988). The 
geo-electric sequence suggests a subsurface geology characterized by alternation of sands/gravels, clay/silt and sandstone occurring at varying depths with variable thicknesses. The sand and gravel layers constitute the aquiferous units in the study area. The geo-electric parameters of the aquifer units were determined from the interpretation of the sounding curves, assisted by the distinctive resistivity contrasts between the discrete geo-electric layers. The upper and lower aquifer horizons works are referred to as the surficial (upper) and intermediate (lower) aquifers respectively.

The curves obtained from the computer iteration were used to construct four interpretive sections $\mathrm{p} 1, \mathrm{p} 2, \mathrm{p} 3$, and p4 column from right to left taken in the north-south directions and vertically for 2-dimensional image of the geo-electric cross section and east-west directions and horizontally for the 3-Dimensional imaging for the hexagonal at three different sections of the location area. The sections (Figures 4-6) reveal that the surficial and intermediate aquifers are overlain in places by materials with variable thickness and resistivity parameters. In section $\mathrm{AB}$ (Figure 10), at the extreme right of the location area, the resistivity of materials overlying the upper aquifer ranges from $2 \Omega \mathrm{m}$ to $5622 \Omega \mathrm{m}$ as revealed by the geo-electric sections. The depth to the top of the aquifer varies from $20.5 \mathrm{~m}$ to $39 \mathrm{~m}$. The high resistivity of the top layers may correspond to the unsaturated zone, as observed in Singh (1984). The depth to the intermediate aquifer ranges from $52 \mathrm{~m}$ to $79.8 \mathrm{~m}$. In the area, depths to the top of the aquifer horizons tend to increase southward.

The thickness and resistivity parameters of materials overlying an aquifer are important parameters in the assessment of the vulnerability of the underling aquifer (Telford et al., 2001). In geo-electric section AB, a north-south cross-section, depths of occurrences range from 16.1 to $48.3 \mathrm{~m}$ and 28.1 to $96.4 \mathrm{~m}$ in the upper and intermediate aquifers respectively. The northwest-southeast section reveals that depth to the upper aquifer ranges from $15.5 \mathrm{~m}$ to $31.5 \mathrm{~m}$, while that of the intermediate aquifer varies between $29.7 \mathrm{~m}$ and $48.5 \mathrm{~m}$. The geo-electric cross sections and the 3-D images of the three zones show that the two aquifer units generally dip southward. The 3-D images showing the depth to the top of the aquifer units are shown. The constructed geo electric sections from the VES results show that the surfacial and intermediate aquifers are highly variable in thickness across the area. In the former, thickness ranges from $5.1 \mathrm{~m}$ to $49.4 \mathrm{~m}$ with a mean value of $25.5 \mathrm{~m}$.

\subsection{Summary of Findings}

The apparent resistivity measured at the field provides a guideline for establishing the geo-electric layers. The four geo-electric section derived from the obtained VES data has provided information on the distribution of aquifer system in the area under investigation, in which the aquifer system is not just evenly distributed, but the potentiality of groundwater increases in the south-eastern direction. The thickness of the aquifer depends on the closeness of the bed rock to the surface while the volume of the water in the aquifer depends on the closeness of the aquifer to the River Niger. The geo-electric layers reveals that the aquifer system in the study area is being recharge mainly by the nearby River Niger.

Also it was established that some of the high hill basement complex rocks (crystalline rocks) reduces the conductivity of the groundwater into the adjacent valley which renders such valley non-aquiferous, although such valley are permeable as revealed by the 3-D image of groundwater distribution. Another striking observation from the geo-electric sections was that the crystalline basement rocks very close to the River Niger were heavily weathered while those far away from the flowing river were just slightly weathered and this gives a characteristically thickening of the aquiferous unit towards the river Niger.

\section{Conclusion}

The present study has established that the flood plain of River Niger at Jebba area has good groundwater potential especially in the south-eastern portion of the area under investigation, which corresponds with the main fracture direction in the area. It was also ascertained that the groundwater system in the area flows toward south-eastern part of the area in agreement with the VES findings and principal joint direction. 


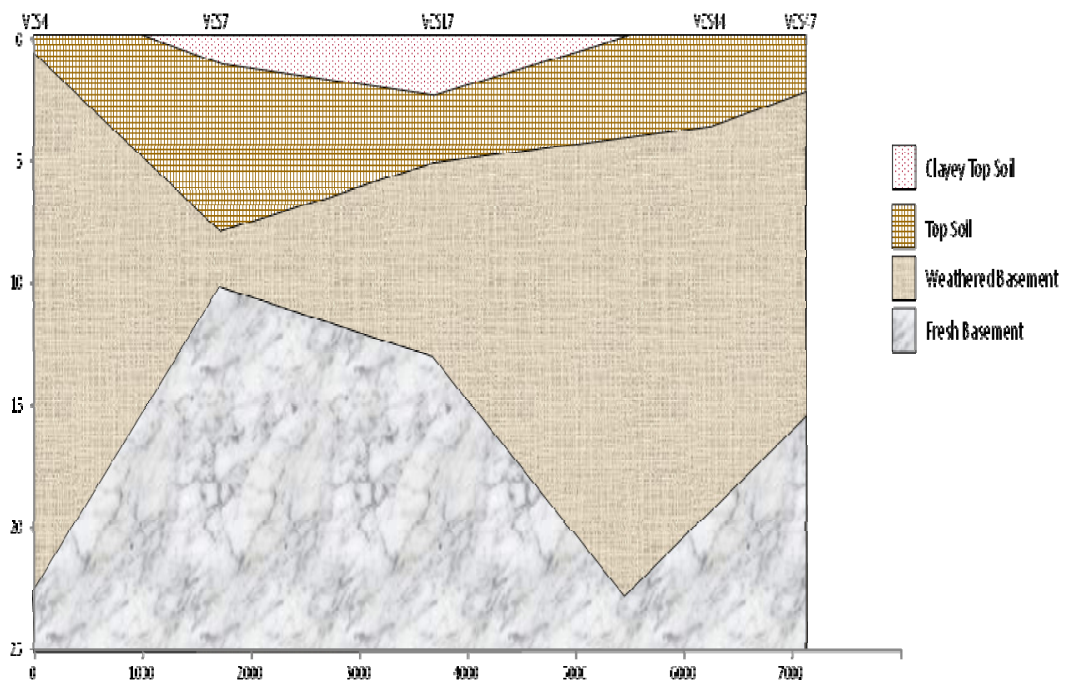

Figure 3. Geoelectric cross-section along ves 4, 7, 17, 44, 47

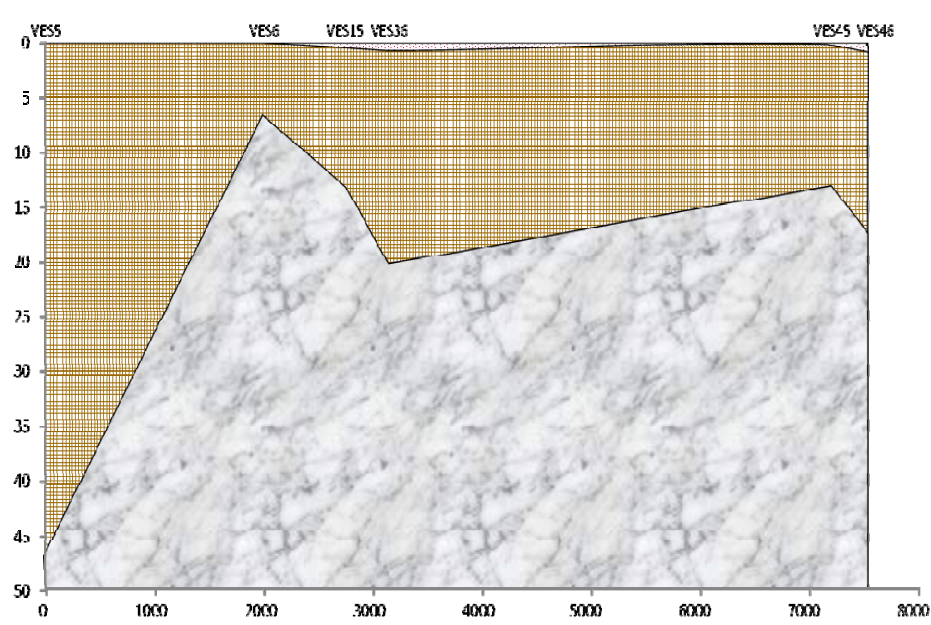

Figure 4. Geoelectric cross-section along VES 5, 6, 15, 36, 45, 46

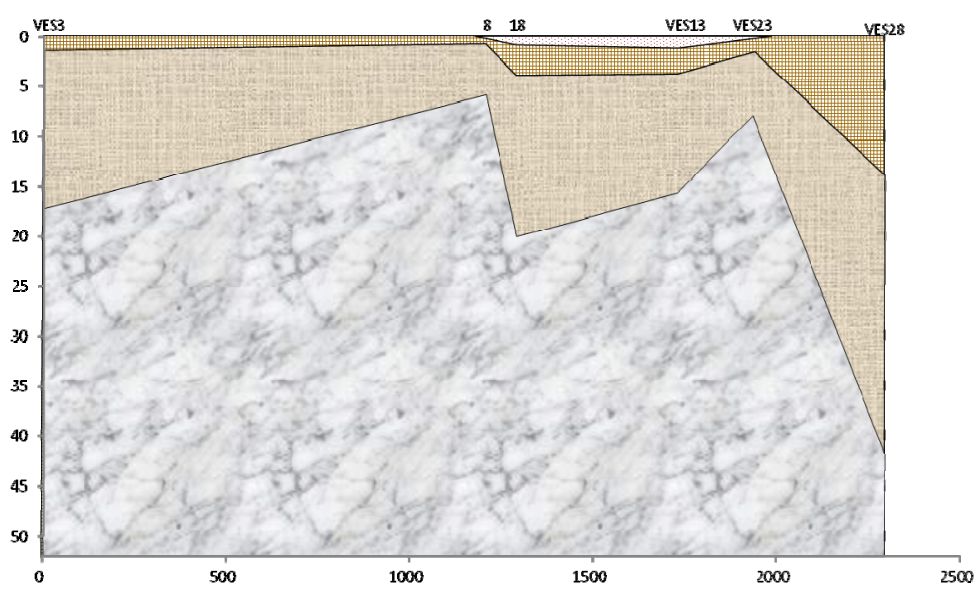

Figure 5. Geoelectric cross-section along VES 3, 8, 18, 13, 23, 28 


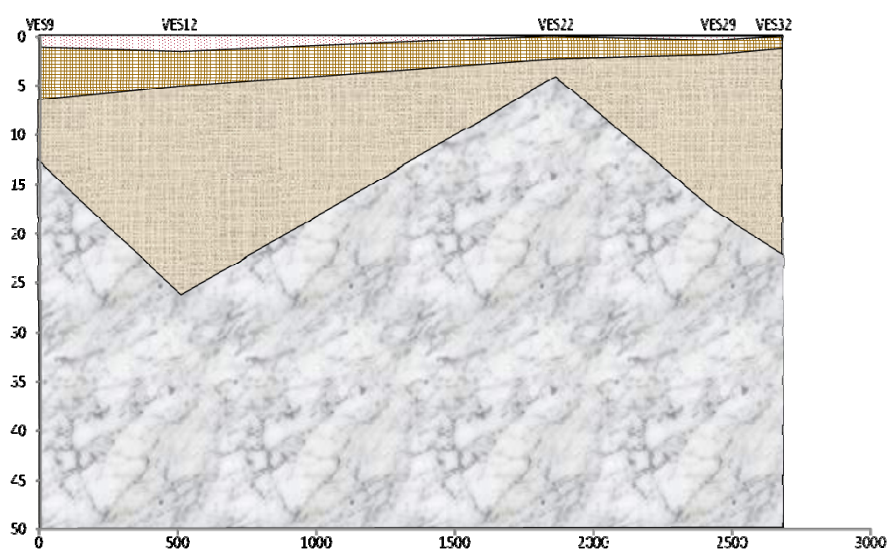

Figure 6. Geoelectric cross-section along VES 9, 12, 22, 29, 32

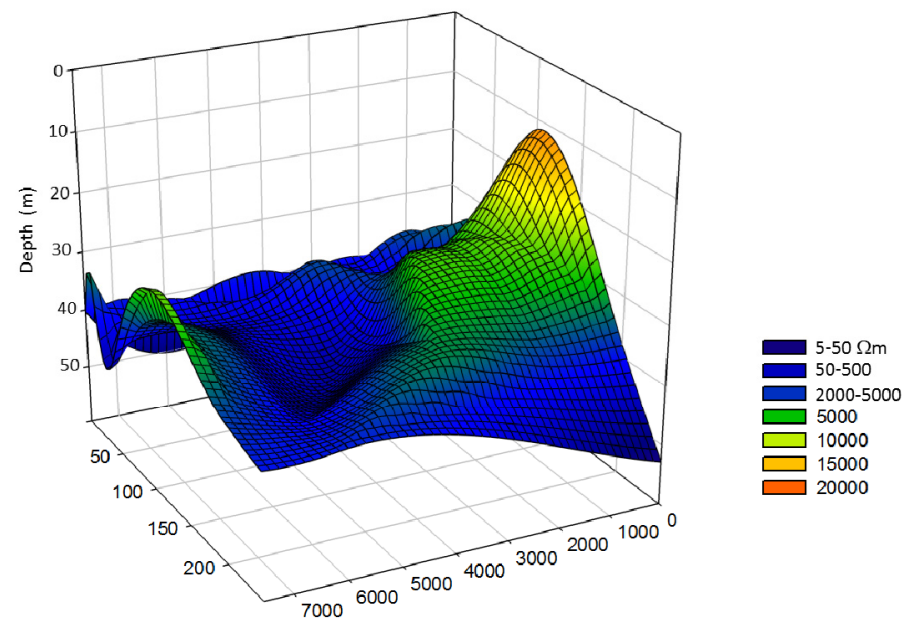

Figure 7. 3D Imaging of groundwater distribution at the south-eastern bank of the river Niger

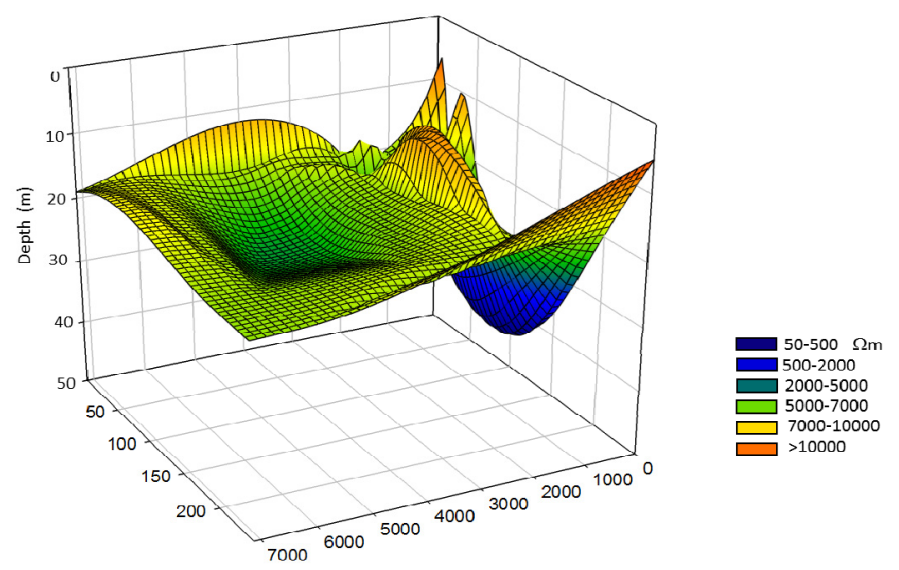

Figure 8. 3D Imaging of groundwater distribution at the north-western bank of the river Niger. 


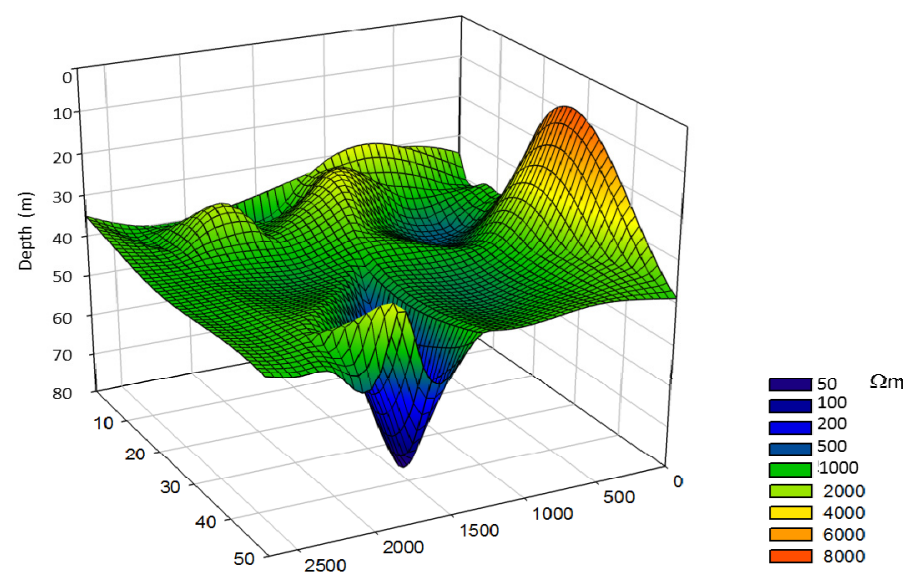

Figure 9. 3D Imaging of groundwater distribution at the north-eastern bank of the river Niger

\section{References}

Ajibade, A. C. (1982). The origin of older granites of Nigeria: some evidence from the Zungeru region, Nigeria. Journal of Mining and Geology, 19(1), 223-230.

Ajibade, A. C., \& Woakes, M. (1976). Proterozoic crustal development in the pan-african regime of Nigeria. In C. A. kogbe (Ed.), (pp. 57-63). Geology of Nigeria. Rock-view, Nigeria, LTD.

Alao, D. A. (2000). Geophysical investigation of structure controlled groundwater aquifer in the south western Nigeria. International Journal of Urban and Regional Affair, 4(2), 42-50.

Amadi, A. N. (2010). Hydrogeological and geophysical study of Bosso area of Minna, North-central Nigeria. Bayero Journal of physics and Mathmatical Science, 3(1), 66-73.

Amadi, A. N., \& Olasehinde, P. I. (2010). Application of remote sensing techniques in hydrogeological mapping of part of Bosso area, Minna, North-central Nigeria. International Journal of physical Science, 5(9), $1465-1474$.

Falconer, D. I. (1971). The geology and geography of Northern Nigeria. Macmillian, London, p. 56.

McCurry, P. (1976). The geology of the precambrain to lower Paleozoic rocks of Northern Nigeria. A review In C. A. Kogbe (Eds.). (pp. 15-39). Geology of Nigeria Elizabeth publishing Co. Lagos.

Schwarz, S. D., (1998). Application of geophysical groundwater exploration in Tssolt River Basin. Water Resources, 2, 23-28.

Selemo, A. O. I., Okeke, P. O., \& Nwankwor, G. I. (1995). An appraisal of usefulness of VES in groundwater exploration in Nigeria. Water Resources, 6(1\&2), 61-67.

Singh, C. L. (1984). Role of surface geophysical methods for groundwater exploration in hard rocks areas. Proceedings of international workshop on rural hydrology and hydraulics in fissured basement zones, 59-68.

Telford, W. N., Geldart, L. P., \& Shriff, R. E. (2001). Applied geophysics (2nd ed.). Cambridge. p. 770.

Truswell, J. F., \& Cope, R. N., (1963). The geology of parts of Niger and Zaria province, Northern Nigeria, Bulletin No. 29, Published by the Nigerian Geological Survey.

Zohdy, A. A., Eaton, C. P., \& Mabey, D. R. (1974). Application of surface geophysics to groundwater investigation. Tech. Water Resources Investigation, Washington, U.S Geological Survey No. 2401-2543. 